\title{
PENGEMBANGAN BAHAN AJAR BERBASIS MULTIMEDIA INTERAKTIF PADA PEMBELAJARAN KETRAMPILAN KOMPUTER DAN PENGELOLAAN INFORMASI
}

\author{
Ilyas $^{1}$ dan R. Mursid ${ }^{2}$ \\ SMK Negeri 3 Medan ${ }^{1}$ dan Universitas Negeri Medan ${ }^{2}$ \\ ilyas@yahoo.com ${ }^{1}$ dan mursid.tp@gmail.com ${ }^{2}$
}

\begin{abstract}
Abstrak: Penelitian ini bertujuan untuk : (1) Mengembangkan bahan ajar berbasis multimedian interaktif sebagai media pembelajaran pada mata pelajaran KKPI, (2) Mengetahui tingkat kelayakan bahan ajar berbasis multimedia interaktif sebagai media pembelajaran pada mata pelajaran KKPI. Penelitian ini merupakan penelitian Research and Development $(R \& D)$ dengan prosedur penelitian menggunakan model Borg \& Gall. Pengembangan bahan ajar berbasis multimedia interaktif, terdiri dari 4 tahap, yaitu: Analisis Kebutuhan, Desain Pembelajaran, Desain pengembangan, Uji Coba dan Revisi Produk. Penentuan tingkat kelayakan bahan ajar berbasis multimedia interaktif berdasarkan uji validasi para ahli dan uji coba kepada siswa serta dilanjutkan dengan uji efektifitas. Secara keseluruhan, berdasarkan penilaian ahli materi, ahli desain dan ahli media serta hasil uji coba pada siswa serta uji efektifitas, maka dapat disimpulkan bahwa bahan ajar berbasis multimedia interaktif pada pembelajaran layak digunakan dan lebih efektif meningkatkan hasil belajar siswa.
\end{abstract}

Kata kunci : Multimedia Interaktif, Pengembangan bahan ajar. Keterampilan computer dan pengelolaan informasi

Abstract: This study aims to: (1) Develop multimedian based interactive teaching materials as a medium of learning in subjects KKPI, (2) Determine the feasibility of interactive multimedia based teaching materials as a medium of learning in subjects KKPI. This study is a Research and Development $(R \& D)$ with research procedures using models Borg \& Gall. Development of interactive multimedia based teaching materials, consists of four steps: Needs Analysis, Design Education, Design development, Testing and Product Revision. The determination of the feasibility of interactive multimedia based teaching materials based on test validation and testing experts to students and continued to test effectiveness. Overall, based on expert assessment of materials, design experts and media experts as well as the test results on the students as well as the effectiveness of the test, it can be concluded that the interactive multimedia teaching materials based on learning appropriate to use and more effective in improving student learning outcomes.

Keywords: Interactive Multimedia, development of teaching materials. Computer and information management skills

\section{PENDAHULUAN}

Pendidikan kejuruan sebagai bagian dari sistem pendidikan nasional adalah pendidikan khusus yang direncanakan untuk menyiapkan peserta didik guna memasuki dunia kerja, serta mengembangkan sikap profesional di bidang-bidang profesi tertentu. Lulusan pendidikan kejuruan diharapkan menjadi manusia produktif yang mampu bersaing untuk masuk lapangan kerja global. Tujuan pendidikan menengah kejuruan di Indonesia menurut Permendiknas nomor 22 tahun 2006 adalah untuk meningkatkan kecerdasan, pengetahuan, kepribadian, akhlak mulia serta keterampilan untuk hidup mandiri dan mengikuti pendidikan lanjut sesuai dengan kejuruannya.

Usaha pemerintah untuk merespon tuntutan perubahan kehidupan lokal, nasional, dan global serta perkembangan informasi, ilmu pengetahuan, teknologi, seni, desentralisasi, dan hak asasi manusia diantaranya adalah dengan mengintegrasikan mata pelajaran Keterampilan Komputer dan Pengelolaan Informasi (KKPI) ke dalam kurikulum SMK. Tujuannya adalah untuk membekali peserta didik agar mampu beradaptasi dengan dunia kerja, perkembangan dunia, dan pendidikan pada jenjang yang lebih 
tinggi serta mendukung pembentukan kompetensi program keahlian serta memudahkan peserta didik mendapatkan pekerjaan yang berskala nasional maupun internasional. Standar isi mata diklat KKPI untuk SMK menyatakan bahwa tujuan mata pelajaran KKPI adalah agar peserta didik memiliki kemampuan untuk : (a) menggunakan teknologi komputer dalam kehidupan seharihari, dan (b) mengaplikasikan komputer sesuai dengan standar kompetensi kerja.

Dari hasil analisis kebutuhan yang dilakukan terhadap 34 orang guru normatif/adaftif menunjukkan bahwa hampir semua guru atau $100 \%$ belum pernah menggunakan bahan ajar berbasis multimedia dan $97,06 \%$ dari guru adaptif/normatif menyatakan membutuhkan bahan ajar berbasis multimedia. Demikian juga hasil angket yang disebarkan kepada 70 orang peserta didik, $100 \%$ peserta didik menginginkan penggunaan bahan ajar berbasis multimedia dalam pembelajaran dan hanya $4,28 \%$ yang menyatakan pernah mengetahui bahan ajar berbasis multimedia.

Minimnya penggunaan media dan bahan ajar berbasis multimedia di SMK Negeri 3 Medan diduga berdampak pada hasil belajar peserta didik, khususnya hasil belajar pada mata pelajaran KKPI. Data di atas menunjukkan bahwa hasil belajar peserta didik dalam mengoperasikan software Microsoft excel pada umumnya $(46,43 \%)$ nilai peserta didik masih berada pada batas nilai Kriteria Ketuntasan Minimal (KKM) yang ditetapkan dalam Standar Kompetensi mengoperasikan software Microsoft excel, yaitu nilai 75, dan peserta didik yang mampu mencapai nilai $\geq 80$ hanya 22,14 $\%$, sedangkan peserta didik yang memperoleh nilai $\leq 75$ mencapai $19,28 \%$. Tingginya persentase peserta didik yang hanya mampu mencapai nilai rata-rata KKM menunjukkan bahwa masih diperlukan upaya-upaya untuk meningkatkan hasil belajar peserta didik. Hasil belajar yang lebih baik dalam mata pelajaran KKPI harus diupayakan karena kompetensi ini sangat dibutuhkan, khususnya peserta didiksiswi SMK Negeri 3 Medan yang lulusannya dipersiapkan untuk mampu berkompetisi dalam ketatnya persaingan dunia kerja saat ini dan masa mendatang.

Penggunaan multimedia akan sangat membantu pencapain tujuan pembelajaran. Menurut Daryanto (2012: 53) “ Multimedia Pembelajaran berguna untuk menyalurkan pesan (pengetahuan, ketrampilan, dan sikap) serta dapat merangsang pilihan, perasaaan, perhatian, dan kemauan siswa sehingga secara sengaja proses belajar terjadi, bertujuan, dan terkendali."

Sedangkan Dick \& Carey (2005:239), menyatakan bahwa bahan ajar merupakan seperangkat materi/substansi pelajaran (teaching material) yang disusun secara sistematis, menampilkan sosok utuh dari kompetensi yang akan dikuasai oleh peserta didik dalam kegiatan pembelajaran.

Menurut Prastowo (2011:24-25) fungsi bahan ajar dapat dibedakan atas: (1) bagi pendidik antara lain menghemat waktu, merubah guru menjadi fasilitator, mengefektifkan pembelajaran, sebagai pedoman dan alat evaluasi, (2) bagi peserta didik dapat digunakan kapan dan dimanapun, belajar sesuai kecepatan, menggali potensi peserta didik, dan pedoman untuk mengarahkan aktivitas dalam pembelajaran, (3) bagi strategi pembelajaran bahan ajar dapat berfungsi sebagai pembelajaran klasikal, individual dan kelompok.

Sedangkan Smaldino, Lowther \& Russell (2011:11) mengatakan bahwa belajar merupakan pengembangan pengetahuan baru, keterampilan, atau sikap sebagai akibat interaksi individu dengan suatu informasi atau lingkungan. Demikian juga Cronbach (dalam Riyanto, 2009: 5) menyatakan bahwa belajar merupakan perubahan prilaku sebagai hasil dari pengalaman. Menurut Cronbach bahwa belajar yang sebaik-baiknya adalah dengan mengalami sesuatu menggunakan pancaindra. Dengan kata lain, bahwa belajar adalah cara mengamati, membaca, meniru, mengintimasi, mencoba sesuatu, mendengar, dan mengikuti arah tertentu.

Senada dengan pendapat diatas, menurut Hamalik (2009: 28) "Belajar adalah suatu proses perubahan tingkah laku individu melalui interaksi dengan lingkungan". Pendapat yang sama juga dikemukakan Sadiman (2009: 2) yang menyatakan bahwa belajar adalah suatu proses yang kompleks yang terjadi pada semua orang dan berlangsung seumur hidup, sejak dia masih bayi hingga keliang lahat nanti. Salah satu pertanda bahwa seseorang telah belajar adalah adanya perubahan tingkah laku dirinya. Perubahan tingkah laku tersebut menyangkut baik perubahan yang bersifat pengetahuan (kognitif) dan ketrampilan(psikomotor) maupun yang menyangkut nilai dan sikap (afektif). 
Selanjutnya Rusman (2013: 83) menyatakan bahwa belajar pada hakekatnya adalah proses interaksi terhadap semua situasi yang ada di sekitar individu peserta didik. Belajar dapat dipandang sebagai proses yang diarahkan kepada pencapaian tujuan dan proses berbuat melalui berbagai pengalaman yang diciptakan oleh guru.

Driscoll (1985:334-336) menyatakan bahwa menurut Bloom ada tiga domain hasil belajar mencakup kemampuan kognitif, afektif dan psikomotorik. Sementara menurut Eggen \& Kauchak, (2012: 10) untuk membantu guru memahami secara lebih baik perbedaanperbedaan dalam berpikir, Benjamin Bloom mengembangkan satu sistem untuk mengklasifikasikan tingkat-tingkat prilaku intelektual yang penting bagi pembelajaran. Hasilnya adalah "Taksonomi Bloom". Taksonomi tersebut mengklasifikasikan berpikir ke dalam enam tingkat yaitu: (1) pengetahuan, (2) pemahaman, (3) penerapan, (4) analisis, (5) sintesis, dan (6) evaluasi. Teori pembelajaran kognitif ini yang ditulis oleh Bloom hampir 60 tahun yang lalu (tahun 1956) telah digunakan secara luas diberbagai jenjang pendidikan di seluruh dunia. Anderson \& Krathwohl (dalam Suparman, 2012:140), telah melalukan revisi terhadap taksonomi Bloom dengan menerbitkan buku A Taxonomy for Learning.

Lebih lanjut Miarso (2004:458), media pembelajaran merupakan sarana untuk memberikan rangsangan bagi si pelajar supaya proses belajar terjadi. Pendapat yang sama juga disampaikan Sadiman (2003: 6), yang menyatakan bahwa media adalah perantara atau penghantar pesan dari pengirim kepada penerima pesan. Demikian juga menurut Daryanto (2012: 4), media adalah sarana perantara yang digunakan dalam proses pembelajaran.

Menurut Arsyad (2013: 4), media pembelajaran adalah komponen sumber belajar atau wahana fisik yang mengandung materi instruksional di lingkungan peserta didik yang dapat merangsang peserta didik untuk belajar. Sedangkan menurut Munadi (2013: 8) media pembelajaran dapat dipahami sebagai "segala sesuatu yang dapat menyampaikan dan menyalurkan pesan dari sumber secara terencana sehingga tercipta lingkungan belajar yang kondusif dimana penerimanya dapat melakukan proses belajar secara efisien dan efektif'. Dengan demikian dapat dipahami bahwa tujuan pemanfaatan media dalam proses pembelajaran adalah untuk mengefektifkan dan mengefesiensikan proses pembelajaran yang dilakukan guru.

Mayer (2009: 3) mendefinisikan multimedia sebagai presentasi materi dengan menggunakan kata-kata sekaligus gambargambar, yang dimaksud dengan kata disini adalah materinya disajikan dengan verbal form atau bentuk verbal. Lebih lanjut Mayer (2009: 64) menyebutkan bahwa multimedia merupakan sarana pendukung dalam pengiriman pesanpesan pembelajaran, yakni dengan memanfaatkan pancaindera manusia untuk menerima pesan-pesan instruksional. Meyer (2009:11) juga mengatakan ada tiga sudut pandang multimedia dalam pembelajaran yaitu media pengiriman, mode presentasi, dan modalitas sensori.

Interaktif berarti bersifat saling mempengaruhi, artinya antara pengguna (user) dan media (program) ada hubungan timbal balik, user memberikan respon terhadap permintaan/tampilan media (program) kemudian dilanjutkan dengan penyajian informasi konsep berikutnya yang disajikan oleh media (program) tersebut. Rob Philips seperti dikutip Ali (2009:11) menjelaskan bahwa makna interaktif sebagai suatu proses pemberdayaan peserta didik untuk mengendalikan lingkungan belajar. Dalam konteks ini lingkungan belajar yang dimaksud adalah belajar dengan menggunakan komputer. Klasisifikasi interaktif dalam lingkup multimedia pembelajaran bukan terletak pada sistem hardware, tetapi lebih mengacu pada karakteristik belajar siswa dalam merespon stimulus yang ditampilkan layar monitor computer.

Sedangkan menurut Daryanto (2012: 53) Multimedia interaktif terbagi menjadi dua kategori, yaitu multimedia linear dan multimedia interaktif. Multimedia linear adalah suatu multimedia yang tidak dilengkapi dengan alat pengontrol apapun yang dapat dioperasikan oleh pengguna. Multimedia ini berjalan sekuensial (berurutan), contohnya; TV dan Film. Sedangkan multimedia interaktif adalah suatu multimedia yang dilengkapi dengan alat pengontrol yang dapat dioperasikan oleh penggguna sehingga pengguna dapat memilih sesuatu yang dikehendakinya untuk proses selanjutnya.

Menurut Munadi (2013:8) bahwa tujuan pemanfaatan media dalam proses pembelajaran 
adalah untuk mengefektifkan dan mengefisiensikan proses pembelajaran itu sendiri. Media juga dapat membantu untuk meningkatkan interaksi antar pengajar dan pelajar, dan membuat proses belajar yang berpusat pada pelajar (student oriented). Dengan kata lain, penggunaan media menggunakan audio visual atau komputer media dapat membantu peserta didik memperoleh pelajaran bermanfaat. Guru sebagai pengembang media pembelajaran harus mengetahui perbedaan pendekatan-pendekatan dalam belajar agar dapat memilih strategi pembelajaran yang tepat. Strategi pembelajaran harus dipilih untuk memotivasi para guru, memfasilitasi proses belajar, membentuk manusia seutuhnya, melayani perbedaan individu, mengangkat belajar bermakna, mendorong terjadinya interaksi, dan memfasilitasi belajar kontekstual, Terdapat beberapa teori belajar yang melandasi penggunaan teknologi/komputer dalam pembelajaran yaitu teori behaviorisme, kognitifisme dan konstruktivisme.

Menurut teori behavioristik, belajar adalah perubahan tingkah laku sebagai akibat adanya interaksi antara stimulus dan respon. Teori ini menekankan pada terbentuknya perilaku yang tampak sebagai hasil belajar. Menurut Thorndike, salah seorang penganut paham behavioristik (dalam Hergenhanhn \& Olson, 2010:60) mengatakan bahwa bentuk belajar paling dasar dari proses belajar adalah trial and error learnig (belajar dengan uji coba), atau yang disebutnya sebagai selecting and connecting (pemilihan dan pengaitan). Selanjutnya Thorndike (dalam Hergenhanhn \& Olson, 2010:65) mengatakan jika suatu respon diikuti dengan satisfying state of affair ( keadaan yang memuaskan), kekuatan koneksi akan bertambah. Jika respon diikuti dengan annoying state of affair (keadaan yang menjengkelkan), kekuatan koneksi itu akan menurun. Dalam terminologi modern, jika suatu stimulus menimbulkan suatu respon, yang pada gilirannya menimbulkan penguatan (reinforcement), maka koneksi S-R akan menguat. Sebaliknya jika stimulus menimbulkan respon yang pada gilirannya menimbulkan hukuman, maka koneksi S-R akan melemah.

Wotruba \& Wright (dalam Miarso, 2005: 536) menyatakan bahwa ada tujuh indikator yang menunjukkan pembelajaran yang efektif antara lain; (a) pengorganisasian pembelajaran dengan baik; (b) komunikasi secara efektif; (c) penguasaan dan antusiasme pada mata diklat; (d) sikap positif terhadap peserta didik; (e) pemberian nilai ujian yang adil; (f) keluwesan dalam pendekatan pengajaran; dan (g) hasil belajar peserta didik yang baik.

Miarso (2005: 536) mengatakan bahwa pembelajaran yang efektif adalah yang menghasilkan belajar yang bermanfaat dan bertujuan bagi peserta didik, melalui prosedur yang tepat. Definisi ini mengandung dua indikator yang penting, yaitu terjadinya belajar pada peserta didik dan apa yang dilakukan oleh guru. Oleh sebab itu prosedur pembelajaran yang dipakai oleh guru dan bukti peserta didik belajar akan dijadikan fokus dalam usaha pencapaian efektifitas pembelajaran.

$$
\text { Menurut Mayer (2009:108) }
$$

mengatakan bahwa beberapa penelitian tentang penggunaan multimedia dalam pembelajaran membuktikan bahwa menyajikan penjelasan verbal tentang bagaimana suatu sistem bekerja tidak menjamin seseorang dapat memahami penjelasan tersebut. Penelitian juga menemukan bukti bahwa cara yang efektif untuk membantu agar informasi ilmiah dapat lebih mudah dipahami ialah melalui penjelasan informasi secara visualisasi dalam format multimedia.

$$
\text { Selanjutnya Hamalik (2002: 20) }
$$

menyatakan bahwa penggunaan media pengajaran sangat membantu keefektifan proses pembelajaran dan penyampaian informasi (pesan dan isi pelajaran). Kehadiran media dalam pembelajaran juga dikatakan dapat membantu peningkatan pemahaman peserta didik, penyajian data/informasi lebih menarik dan terpercaya serta memudahkan penafsiran data dalam memperoleh informasi. Hal lain yang mendukung efektifitas pembelajaran adalah tersedianya sumber belajar dengan memanfaatkan media pembelajaran secara tepat merupakan faktor pendorong dan pemelihara kegiatan pembelajaran yang produktif, efektif dan efisien.

Upaya-upaya yang dapat dilakukan untuk mengefektifkan pembelajaran salah satunya adalah dengan penggunaan multimedia dalam pembelajaran yang bersifat interaktif. Pembelajaran dengan menggunakan multimedia akan lebih menarik, lebih efektif, efisiensi waktu pembelajaran, meningkatkan kualitas pembelajaran sehingga tujuan dari suatu kegiatan pembelajaran dapat tercapai. Munadi (2013: 152) menyatakan bahwa kelebihan yang 
dimiliki oleh multimedia interaktif sebagai media pembelajaran antara lain : (1) peserta didik terlibat secara auditif, visual, dan kinetik; (2) memberikan iklim afeksi secara individual; (3) Meningkatkan motivasi belajar; (4) Memberkan umpan balik; dan (5) kontrol penggunaanya sepenuhnya berada pada penggunanya.

Sejalan dengan pendapat diatas Seels \& Richey (1944: 38-39) menyatakan bahwa hasil dari pengembangan adalah terciptanya suatu produk tertentu dalam bentuk fisik. Salah satu penggerak dari kawasan pengembangan adalah adanya manifestasi fisik dari teknologi yang berupa perangkat keras (Hardware), perangkat lunak (Software) dan bahan pembelajaran. Demikian juga Sugiyono (2012:297) menyatakan bahwa penelitian dan pengembangan atau Research and Development adalah metode penelitian yang digunakan untuk menghasilkan produk tertentu, dan menguji keefektifan produk tersebut.

Seels \& Richey (1994:10) mengungkapkan teknologi pembelajaran adalah teori dan praktek dalam desain, pengembangan, pemanfaatan, pengelolaan dan penilaian proses dan sumber belajar. Definisi pada tahun 2004 dikeluarkan oleh AECT yaitu "Educational technology is the studyand ethical practice of fasicilitating learning and improving performance by creating, using and managing appropriate technological processes andresources" (AECT, 2004:3). Konsep definisi versi AECT 2004 Teknologi Pendidikan adalah studi dan etika praktek untuk memfasilitasi pembelajaran dan meningkatkan kinerja melalui penciptaan, penggunaan, dan pengaturan proses dan sumber daya teknologi. Tujuan utamanya masih tetap untuk memfasilitasi pembelajaran (agar efektif, efisien dan menarik) dan meningkatkan kinerja. Definisi pada tahun 2008 sudah lebih spesifik karena menekankan pada studi \& etika praktek, sama yang dikeluarkan oleh AECT pada tahun 2004 yang dikemukakan oleh Januszewski \& Molenda (2008:1) "Educational Technology: A Definition with Commentary "Educationa ltechnology is the study and ethical practice of fasicilitating learning and improving performance by creating, using and managing appropriate technological processes and resources".

Bahan ajar berbasis multimedia telah banyak digunakan dalam beberapa tahun terakhir. Ini didukung oleh perkembangan yang sangat pesat dibidang teknologi informasi, komunikasi, dan komputer, Asyhar (2011:172). Berbagai bentuk format bahan ajar berbasis multimedia sudah dikembangkan, mulai dari yang sederhana seperti bahan presentasi hingga yang rumit dan komplek seperti bahan ajar interaktif, e-learning.

Bahan ajar multimedia adalah media pembelajaran yang berbasis teknologi multimedia, Asyhar (2011:172). Bahan ajar berbasis multimedia paling sederhana dan banyak dipakai adalah bahan presentasi menggunakan power point. Dalam pembelajaran berbasis multimedia, peserta didik dapat mempelajari materi ajar yang ada dalam CD/VCD interaktif yang dilengkapi dengan kuis untuk latihan. Dalam hal ini pendidik atau pengembang akan menyusun bahan ajar, kemudian dikonversi kedalam bentuk format digital. Bahan ajar ini kemudian dikemas dalam bentuk CD dan digunakan oleh peserta didik secara berulang-ulang secara individual atau kelompok hingga materi dapat dipahami. Peserta didik dapat melakukan evaluasi terhadap pencapaian belajar melalui kuis atau latihan yang disediakan secara interaktif.

Menurut Mayer (2009:93) prinsip dalam pembelajaran dengan multimedia adalah peserta didik bisa belajar lebih baik dari katakata dan gambar daripada kata-kata saja. Lebih lanjut Mayer mengungkapkan alasan secara teoretis bahwa "saat kata-kata dan gambar disajikan secara bersamaan, murid punya kesempatan untuk mengkonstruksi modelmodel mental verbal dan pictorial dan membangun hubungan diantara keduanya. Sedangkan alasan secara empiris dijelaskan Mayer dengan melakukan tes, dalam enam dari sembilan tes, murid yang menerima teks dan ilustrasi atau narasi dan animasi terbukti berkinerja lebih baik dalam tes retensi daripada murid yang menerima teks saja atau narasi saja. Dan dalam sembilan dari sembilan tes, murid yang menerima teks dan ilustrasi atau narasi dan animasi terbukti berkinerja lebih baik dalam tes transfer daripada murid yang menerima teks saja atau narasi saja.

Setiap format bahan ajar multimedia memiliki karakteristik tertentu dan kriteria bahan pembelajaran multimedia yang baik ditentukan oleh karakteristiknya. Namun secara umum dapat digambarkan beberapa kriteria bahan ajar multimedia yang baik sebagai berikut, Asyhar (2011:173); (1) tampilan harus menarik baik dari bentuk gambar maupun 
kombinasi warna yang digunakan, (2) narasi atau bahasa harus jelas dan mudah dipahami, (3) materi disaajikan secara interaktif, (4) memuat kebutuhan untuk mengakomodasi berbagai model (styles) dalam belajar, (5) sesuai dengan karakteristik peserta didik, karakteristik materi dan tujuan yang ingin dicapai, (6) sesuai dengan sarana pendukung media, (7) proses pembelajaran adalah kontinuitas utuh, bukan sporadik dan kejadian terpisah-pisah, (8) memungkinkan ditampilkan suatu virtual learning environment.

Untuk menghasilkan suatu multimedia pembelajaran yang baik dan tepat sasaran, maka perlu tahap-tahap prosedur umum dalam pembuatan bahan ajar. Menurut Asyhar: (2011:174-176), tahap-tahap prosedur umum dalam pembuatan bahan ajar berbasis multimedia ini adalah : (1) Analisis, (2) pemilihan teknologi, (3) merancang desain, (4) menyusun storyboard dan prototipe, (5) identifikasi dan pengumpulan materi, (6)pembuatan bahan ajar multimedia, (7) uji coba dan fine tuning.

Pada pengembangan bahan ajar berbasis multimedia interaktif pada mata pelajaran KKPI ini terdiri dari 3 materi untuk kompetensi mengoperasikan software Microsoft excel yang akan diajarkan pada peserta didik kelas XI, dengan tujuan pembelajaran adalah peserta didik mampu memahami dan mengoperasikan software microsoft excel. Tampilan materi dalam bentuk teks disertai gambar dan foto dari contoh-contoh untuk mengkonkritkan materi yang bersifat abstrak, serta dilengkapi dengan video tentang petunjuk cara pembuatan media. Semua materi dikemas dalam bentuk $\mathrm{CD}$ pembelajaran yang disajikan secara offline.

Masalah dalam penelitian ini adalah sebagai berikut : (1) Apakah produk pengembangan bahan ajar KKPI berbasis multimedia interaktif layak untuk digunakan sebagai media pembelajaran di SMK Negeri 3 Medan?; (2) Apakah penggunaan produk pengembangan bahan ajar KKPI berbasis multimedia interaktif lebih efektif meningkatkan hasil belajar dibandingkan dengan penggunaaan buku teks plus presentasi power point?

\section{METODE}

Penelitian ini dilaksanakan di SMK Negeri 3 Medan, Jalan STM No 12 B Kampung Baru Medan pada siswa kelas XI Program Studi
Kimia Analisis dan Kimia Industri semester ganjil. Pelaksanaan penelitian ini disesuaikan dengan kalender pendidikan dan untuk pelaksanaan uji coba produk dilakukan dalam bentuk kegiatan belajar mengajar atau proses pembelajaran. Uji coba produk dilakukan dalam kegiatan pembelajaran selama 3 kali pertemuan, masing-masing $2 \times 45$ menit tiap pertemuan. Kegiatan uji coba produk ini dilakukan di laboratorium komputer. Setelah melakukan uji coba produk, selanjutnya dilkukan Uji efektifitas terhadap produk hasil pengembangan. Uji coba dan uji efektifitas produk ini dilaksanakan di SMK Negeri 3 Medan.

Penelitian ini merupakan penelitian dan pengembangan (Research and Development) bahan ajar berbasis multimedia interaktif pada pembelajaran KKPI. Penelitian dan pengembangan ini mencakup proses pengembangan dan uji efektivitas produk sebagaimana dikemukakan Sugiono (2009:407) "Penelitian dan pengembangan atau dalam bahasa Inggrisnya Research and Development adalah metode penelitian yang digunakan untuk menghasilkan produk tertentu, dan menguji keefektifan produk tersebut". Rancangan model penelitian dan pengembangan yang digunakan dalam penelitian ini adalah model pengembangan Borg \& Gall (1983:770). Prosedur pengembangan yang dilakukan dalam penelitian ini adalah untuk menghasilkan bahan ajar berbasis multimedia interaktif pada Kompetensi dasar mengoperasikan software microsoft excel. Dengan merujuk pada model pengembangan Borg \& Gall diatas maka prosedur pengembangan bahan ajar berbasis multimedia interaktif adalah sebagai berikut :

1) Analisis masalah dan kebutuhan untuk mengumpulkan informasi ( kajian pustaka, analisis SK dan KD, dan pengamatan terhadap media ajar yang dipergunakan disekolah dengan Kompetensi dasar mengoperasikan software microsoft excel, identifikasi permasalahan yang dijumpai dalam pengamatan media ajar.

2) Perencanaan pengembangan bahan ajar berbasis multimedia interaktif pada kompetensi dasar mengoperasikan software microsoft excel

3) Menyusun Instrumen untuk uji coba yang berupa lembar angket bagi siswa serta instrumen penilaian bagi ahli desain media pembelajaran, ahli materi /isi bahan ajar dan ahli desain perangkat lunak (ahli IT). 
4) Validasi dari ahli dilakukan dengan menggunakan lembar validasi/kelayakan media ajar.

5) Melakukan revisi kedua yang merupakan hasil analisis dan masukan serta saransaran dari hasil validasi ahli.

6) Uji coba kelompok perorangan yang dilakukan terhadap 3 orang siswa dengan karakteristik siswa kemampuan rendah, sedang dan tinggi. Pengumpulan informasi atau data dengan menggunakan angket (kuesioner).

7) Melakukan revisi ketiga terhadap produk dari hasil uji coba kelompok perorangan apabila membutuhkan revisi.

8) Melakukan uji coba kelompok kecil yang dilakukan terhadap 9 orang siswa dengan karakteristik siswa berkemampuan rendah, sedang dan tinggi.

9) Melakukan revisi keempat terhadap produk dari hasil uji coba kelompok kecil apabila membutuhkan revisi.

10) Melakukan uji coba kelompok lapangan terbatas yang dilakukan terhadap 36 orang siswa. Pengumpulan informasi atau data dengan menggunakan angket (kuesioner).

11) Melakukan revisi kelima terhadap produk dari hasil uji coba kelompok lapangan apabila membutuhkan revisi.

12) Melakukan pengolahan dan analisis data untuk menarik kesimpulan dari hasil penelitian.

13) Hasil akhir, merupakan produk bahan ajar bebasis multimedia interaktif dari hasil revisi keempat yang layak digunakan pada pembelajaran.

14) Uji Efektivitas, adalah untuk melihat sejauh mana produk bahan ajar yang dikembangkan ini efektif meningkatkan hasil belajar peserta didik dibandingkan dengan menggunakan buku teks plus presentasi power point.

\section{HASIL DAN PEMBAHASAN \\ Hasil}

Tabel 1. Penilaian Para Ahli bidang Materi, Desain Pembelajaran, dan Media Pembelajaran

\begin{tabular}{|c|c|c|c|c|}
\hline No & Penilaian Para Ahli & $\begin{array}{c}\text { Jumlah } \\
\text { Skor }\end{array}$ & $\begin{array}{l}\text { Rata- } \\
\text { Rata }\end{array}$ & Kriteria \\
\hline 1 & $\begin{array}{l}\text { Penilaian Media Pembelajaran Interaktif Oleh Ahli Materi } \\
\text { Tentang Kualitas Materi Pembelajaran }\end{array}$ & 8,67 & $86,70 \%$ & $\begin{array}{l}\text { Sangat } \\
\text { Baik }\end{array}$ \\
\hline 2 & $\begin{array}{l}\text { Penilaian Media Pembelajaran Interaktif Oleh Ahli Materi } \\
\text { Tentang Kualitas Strategi Pembelajaran }\end{array}$ & 8,5 & $85 \%$ & $\begin{array}{c}\text { Sangat } \\
\text { baik }\end{array}$ \\
\hline 3 & $\begin{array}{l}\text { Penilaian Media Pembelajaran Interaktif Oleh Ahli Materi } \\
\text { Tentang Sistem Penyampaian Pembelajaran }\end{array}$ & 9 & $90 \%$ & $\begin{array}{l}\text { Sangat } \\
\text { Baik }\end{array}$ \\
\hline 4 & $\begin{array}{l}\text { Penilaian Media Pembelajaran Interaktif Oleh Ahli Desain } \\
\text { Pembelajaran Tentang Aspek Kualitas Desain Pembelajaran }\end{array}$ & 8,14 & $81,40 \%$ & $\begin{array}{c}\text { Sangat } \\
\text { Baik }\end{array}$ \\
\hline 5 & $\begin{array}{l}\text { Penilaian Media Pembelajaran Interaktif Oleh Ahli Desain } \\
\text { Pembelajaran Tentang Aspek Kualitas Desain Informasi }\end{array}$ & 8 & $80 \%$ & $\begin{array}{l}\text { Sangat } \\
\text { Baik }\end{array}$ \\
\hline 6 & $\begin{array}{l}\text { Penilaian Media Pembelajaran Interaktif Oleh Ahli Desain } \\
\text { Pembelajaran Tentang Aspek Kualitas Desain Interaksi }\end{array}$ & 8 & $80 \%$ & $\begin{array}{c}\text { Sangat } \\
\text { Baik }\end{array}$ \\
\hline 7 & $\begin{array}{l}\text { Penilaian Media Pembelajaran Interaktif Oleh Ahli Desain } \\
\text { Pembelajaran Tentang Aspek Kualitas Presentasi }\end{array}$ & 8,286 & $82,86 \%$ & $\begin{array}{c}\text { Sangat } \\
\text { Baik }\end{array}$ \\
\hline 8 & $\begin{array}{l}\text { Penilaian Terhadap Media Pembelajaran Interaktif pada } \\
\text { Pembelajaran Ekonomi Oleh Ahli Desain Pembelajaran }\end{array}$ & 8,36 & $83,65 \%$ & $\begin{array}{c}\text { Sangat } \\
\text { Baik }\end{array}$ \\
\hline 9 & $\begin{array}{l}\text { Penilaian Media Pembelajaran Interaktif Oleh Ahli Rekayasa } \\
\text { Perangkat Lunak Pada Aspek Pemprograman }\end{array}$ & 8,285 & $82,85 \%$ & $\begin{array}{c}\text { Sangat } \\
\text { Baik }\end{array}$ \\
\hline 10 & $\begin{array}{l}\text { Penilaian Media Pembelajaran Interaktif Oleh Ahli Rekayasa } \\
\text { Perangkat Lunak Pada Aspek Kualitas Teknis/Tampilan }\end{array}$ & 8,428 & $84,28 \%$ & $\begin{array}{c}\text { Sangat } \\
\text { Baik }\end{array}$ \\
\hline
\end{tabular}

\section{Deskripsi Data Hasil Uji Coba Tahap II (Uji Coba Perorangan)}

Tabel 2. Skor Penilaian Multimedia Pembelajaran Mata pelajaran KKPI Pada Uji Coba Perorangan di SMK Negeri 3 Medan Tentang Kualitas Materi Pembelajaran

\begin{tabular}{|l|c|c|c|c|c|c|c|}
\hline \multirow{2}{*}{ No } & \multirow{2}{*}{ Indikator Penilaian } & \multicolumn{2}{|c|}{ Reponden } & Jumlah & Rata-rata & \multirow{2}{*}{ Kriteria } \\
\cline { 3 - 5 } & & 1 & 2 & 3 & Skor & \\
\hline
\end{tabular}




\begin{tabular}{|c|c|c|c|c|c|c|c|}
\hline 1 & Kesesuaian materi & 5 & 5 & 5 & 15 & $100,00 \%$ & Sangat baik \\
\hline 2 & Kejelasan petunjuk belajar & 5 & 5 & 5 & 15 & $100,00 \%$ & Sangat baik \\
\hline 3 & $\begin{array}{l}\text { Kemudahan memahami } \\
\text { kalimat pada teks }\end{array}$ & 4 & 4 & 4 & 12 & $80,00 \%$ & Sangat baik \\
\hline 4 & $\begin{array}{l}\text { Kemudahan memahami } \\
\text { pembelajaran }\end{array}$ & 4 & 4 & 4 & 12 & $80,00 \%$ & Sangat baik \\
\hline 5 & Ketepatan urutan penyajian & 5 & 5 & 5 & 15 & $100,00 \%$ & Sangat baik \\
\hline 6 & Kecukupan latihan & 4 & 4 & 4 & 12 & $80,04 \%$ & Sangat baik \\
\hline 7 & Kejelasan umpan balik & 5 & 5 & 5 & 15 & $100,00 \%$ & Sangat baik \\
\hline 8 & $\begin{array}{l}\text { Bantuan belajar dengan } \\
\text { program }\end{array}$ & 5 & 4 & 5 & 14 & $93,33 \%$ & Sangat baik \\
\hline \multicolumn{5}{|c|}{ Rata-rata } & 13,57 & $91,67 \%$ & Sangat baik \\
\hline
\end{tabular}

Tabel 3. .Skor Penilaian Multimedia Pembelajaran Mata pelajaran KKPI Pada Uji Coba Perorangan Tentang Kualitas Teknis atau Tampilan

\begin{tabular}{|c|c|c|c|c|c|c|c|}
\hline \multirow{2}{*}{ No } & \multirow{2}{*}{ Indikator Penilaian } & \multicolumn{3}{|c|}{ Reponden } & \multirow{2}{*}{$\begin{array}{l}\text { Jumlah } \\
\text { Skor }\end{array}$} & \multirow{2}{*}{ Rata-rata } & \multirow{2}{*}{ Kriteria } \\
\hline & & 1 & 2 & 3 & & & \\
\hline 1 & Keindahan tampilan layar & 5 & 5 & 5 & 15 & $100,00 \%$ & Sangat baik \\
\hline 2 & Keterbacaan teks & 5 & 4 & 5 & 14 & $93,33 \%$ & Sangat baik \\
\hline 3 & $\begin{array}{l}\text { Kualitas video, gambar dan } \\
\text { animasi }\end{array}$ & 5 & 5 & 5 & 15 & $100,00 \%$ & Sangat baik \\
\hline 4 & Komposisi warna & 5 & 4 & 5 & 14 & $93,33 \%$ & Sangat baik \\
\hline 5 & Navigasi & 5 & 4 & 5 & 14 & $93,33 \%$ & Sangat baik \\
\hline 6 & Daya dukung musik & 5 & 5 & 4 & 14 & $93,33 \%$ & Sangat baik \\
\hline 7 & Interaksi & 4 & 4 & 5 & 14 & $93,33 \%$ & Sangat baik \\
\hline \multicolumn{5}{|c|}{ Rata-rata } & 14,28 & $95,23 \%$ & Sangat baik \\
\hline
\end{tabular}

\section{Deskripsi Data Hasil Uji Coba Kelompok Kecil (Uji Coba Tahap III)}

Tabel 4. Skor Penilaian Multimedia Pembelajaran Mata pelajaran KKPI Pada Uji Coba Kelompok Kecil Tentang Kualitas Materi Pembelajaran

\begin{tabular}{|c|c|c|c|c|c|c|c|c|}
\hline \multirow{2}{*}{ No } & \multirow{2}{*}{ Indikator Penilaian } & \multicolumn{5}{|c|}{ Responden } & \multirow{2}{*}{ Rata-rata } & \multirow{2}{*}{ Kriteria } \\
\hline & & 1 & 2 & 3 & 4 & 5 & & \\
\hline 1 & Kesesuaian materi & & & & 4 & 5 & $91.11 \%$ & Sangat baik \\
\hline 2 & Kejelasan petunjuk belajar & & & & 4 & 5 & $91.11 \%$ & Sangat baik \\
\hline 3 & $\begin{array}{l}\text { Kemudahan memahami } \\
\text { kalimat pada teks }\end{array}$ & & & & 4 & 5 & $91.11 \%$ & Sangat baik \\
\hline 4 & $\begin{array}{l}\text { Kemudahan memahami } \\
\text { pembelajaran }\end{array}$ & & & & 5 & 4 & $88.89 \%$ & Sangat baik \\
\hline 5 & Ketepatan urutan penyajian & & & & 3 & 6 & $93.33 \%$ & Sangat baik \\
\hline 6 & Kecukupan latihan & & & 1 & 4 & 4 & $86.67 \%$ & Sangat baik \\
\hline 7 & Kejelasan umpan balik & & & & 6 & 3 & $86.67 \%$ & Sangat baik \\
\hline
\end{tabular}




\begin{tabular}{|l|l|l|l|l|l|l|l|l|}
\hline 8 & $\begin{array}{l}\text { Bantuan belajar dengan } \\
\text { program }\end{array}$ & & & & 4 & 5 & $91.11 \%$ & Sangat baik \\
\hline \multicolumn{6}{|c|}{ Rata-rata } \\
\hline
\end{tabular}

Tabel 5. Skor Penilaian Multimedia Pembelajaran Mata pelajaran KKPI Pada Uji Coba Kelompok Kecil Tentang Kualitas Teknis atau Tampilan

\begin{tabular}{|c|l|c|c|c|c|c|c|c|}
\hline \multirow{2}{*}{ No } & \multirow{2}{*}{ Indikator Penilaian } & \multicolumn{5}{|c|}{ Skor Reponden } & Rata-rata & Kriteria \\
\cline { 4 - 9 } & & 1 & 2 & 3 & 4 & 5 & & \\
\hline 1 & Keindahan tampilan layar & & & & 1 & 8 & $97,78 \%$ & Sangat baik \\
\hline 2 & Keterbacaan teks & & & & 4 & 5 & $91.11 \%$ & Sangat baik \\
\hline 3 & $\begin{array}{l}\text { Kualitas video, gambar } \\
\text { dan animasi }\end{array}$ & & & 7 & 2 & $84.44 \%$ & Sangat baik \\
\hline 4 & Komposisi warna & & & & 2 & 7 & $95.56 \%$ & Sangat baik \\
\hline 5 & Navigasi & & & & 6 & 3 & $86.66 \%$ & Sangat baik \\
\hline 6 & Daya dukung musik & & & & 7 & 2 & $84.44 \%$ & Sangat baik \\
\hline 7 & Interaksi & & & 2 & 7 & $95.56 \%$ & Sangat baik \\
\hline \multicolumn{2}{|c|}{ Rata-rata } & & & & & & & \\
\hline
\end{tabular}

\section{Deskripsi Data Hasil Uji Coba Lapangan (Uji Coba Tahap IV)}

Tabel 6. Skor Penilaian Multimedia Pembelajaran Mata pelajaran KKPI Pada Uji Coba Lapangan Tentang Kualitas Teknis atau Tampilan

\begin{tabular}{|c|c|c|c|c|c|c|c|c|}
\hline \multirow{2}{*}{ No } & \multirow{2}{*}{ Indikator Penilaian } & \multicolumn{5}{|c|}{ Reponden } & \multirow{2}{*}{ Rata-rata } & \multirow{2}{*}{ Kriteria } \\
\hline & & 1 & 2 & 3 & 4 & 5 & & \\
\hline 1 & Keindahan tampilan layar & & & & 6 & 30 & $96.67 \%$ & Sangat baik \\
\hline 2 & Keterbacaan teks & & & 2 & 16 & 18 & $88.89 \%$ & Sangat baik \\
\hline 3 & $\begin{array}{l}\text { Kualitas video, gambar } \\
\text { dan animasi }\end{array}$ & & & 2 & 17 & 17 & $88.33 \%$ & Sangat baik \\
\hline 4 & Komposisi warna & & & 2 & 12 & 22 & $91.11 \%$ & Sangat baik \\
\hline 5 & Navigasi & & & 2 & 21 & 13 & $86.11 \%$ & Sangat baik \\
\hline 6 & Daya dukung musik & & & 1 & 15 & 20 & $90.56 \%$ & Sangat baik \\
\hline \multirow[t]{2}{*}{7} & Interaksi & & & & 15 & 21 & $92.22 \%$ & Sangat baik \\
\hline & \multicolumn{6}{|c|}{ Rata-rata } & $90.63 \%$ & Sangat baik \\
\hline
\end{tabular}

Tabel 7. Skor Penilaian Multimedia Pembelajaran Mata pelajaran KKPI Pada Uji Coba Lapangan Tentang Kualitas Materi Pembelajaran

\begin{tabular}{|c|c|c|c|c|c|c|c|c|}
\hline \multirow{2}{*}{ No } & \multirow{2}{*}{ Indikator Penilaian } & \multicolumn{5}{|c|}{ Reponden } & \multirow{2}{*}{ Rata-rata } & \multirow{2}{*}{ Kriteria } \\
\hline & & 1 & 2 & 3 & 4 & 5 & & \\
\hline 1 & Kesesuaian materi & & & & 10 & 26 & $94.00 \%$ & Sangat baik \\
\hline 2 & Kejelasan petunjuk belajar & & & 1 & 13 & 22 & $91.67 \%$ & Sangat baik \\
\hline 3 & $\begin{array}{l}\text { Kemudahan memahami } \\
\text { kalimat pada teks }\end{array}$ & & & 1 & 21 & 14 & $87.22 \%$ & Sangat baik \\
\hline 4 & $\begin{array}{l}\text { Kemudahan memahami } \\
\text { pembelajaran }\end{array}$ & & & & 17 & 19 & $90.56 \%$ & Sangat baik \\
\hline 5 & $\begin{array}{l}\text { Ketepatan urutan } \\
\text { penyajian }\end{array}$ & & & 1 & 15 & 20 & $90.56 \%$ & Sangat baik \\
\hline 6 & Kecukupan latihan & & & 4 & 15 & 17 & $87.22 \%$ & Sangat baik \\
\hline
\end{tabular}




\begin{tabular}{|c|l|l|l|l|l|l|l|l|}
\hline 7 & Kejelasan umpan balik & & & 1 & 20 & 15 & $87.78 \%$ & Sangat baik \\
\hline 8 & $\begin{array}{l}\text { Bantuan belajar dengan } \\
\text { program }\end{array}$ & & & 2 & 14 & 20 & $90.00 \%$ & Sangat baik \\
\hline \multicolumn{6}{|c|}{ Rata-rata } \\
\hline
\end{tabular}

Tabel 8. Rangkuman Persentase Rata-Rata Hasil Penilaian Terhadap Multimedia Pembelajaran Mata pelajaran KKPI

\begin{tabular}{|l|l|c|c|}
\hline No & \multicolumn{1}{|c|}{ Kategorisasi } & $\begin{array}{c}\text { Persentase } \\
\text { Rata-rata }\end{array}$ & Kriteria \\
\hline 1 & Ahli materi & $87.23 \%$ & Sangat Baik \\
\hline 2 & Ahli desain pembelajaran & $81.07 \%$ & Sangat Baik \\
\hline 3 & Ahli media pembelajaran & $83.57 \%$ & Baik \\
\hline 4 & Uji coba perorangan & $92.50 \%$ & Sangat Baik \\
\hline 5 & Uji coba kelompok kecil & $90.40 \%$ & Sangat Baik \\
\hline 6 & Uji coba lapangan & $90.26 \%$ & Sangat Baik \\
\hline & \multicolumn{1}{|c|}{ Rata-rata } & $\mathbf{8 7 . 5 1 \%}$ & Sangat Baik \\
\hline
\end{tabular}

Hipotesis yang diajukan dalam penelitian ini adalah mengetahui keefektifan bahan ajar berbasis multimedia dibandingkan dengan penggunaan buku teks terhadap peningkatan hasil belajar siswa pada mata pelajaran KKPI. Namun untuk menilai keefektifan media, maka kita perlu mengetahui perbedaan hasil belajar yang diajar dengan menggunakan multimedia pembelajaran dengan hasil belajar yang diajar dengan menggunakan buku teks.Untuk menguji hal ini digunakan ujit.

Dari hasil perhitungan efektifitas diatas, dapat disimpulkan bahwa hasil belajar siswa yang diajar dengan menggunakan multimedia pembelajaran $X_{2}=89,61 \%$ atau lebih tinggi dari hasil belajar siswa yang diajar dengan menggunakan buku teks $\left(X_{I}=80,72 \%\right)$. Hasil ini menunjukkan bahwa terdapat rerata peningkatan hasil belajar yang lebih baik pada peserta didik yang melakukan pembelajaran menggunakan bahan ajar berbasis multimedia interaktif dibandingkan dengan menggunakan buku teks dalam pembelajaran KKPI. Sehingga pembelajaran menggunakan bahan ajar berbasis multimedia interaktif tersebut dapat dikatakan lebih efektif meningkatkan hasil belajar siswa.

Dari hasil pengolahan data pada uji $\mathrm{t}$ diperoleh $t_{\text {hitung }}$ sebesar 5,39, sedangkan $t_{\text {tabel }}$ pada taraf $\alpha=0,05$ dengan dk 70 adalah 1,66, maka $t_{\text {hitung }}>\mathrm{t}_{\text {tabel }}$; atau 5,39>1,66. Hasil uji $\mathrm{t}$ yang diperoleh dikatakan signifikan ( hipotesis diterima) jika harga $t_{\text {hitung }}>t_{\text {tabel }}$ untuk taraf signifikasi 0,05. Berdasarkan hasil data maka kesimpulannya adalah terdapat perbedaan hasil belajar siswa yang diajar dengan multimedia pembelajaran dibandingkan dengan hasil belajar siswa yang diajar dengan menggunakan buku teks pada taraf signifikan $0,05(5 \%)$.

\section{Pembahasan}

Pengembangan produk bahan ajar berbasis multimedia pada mata pelajaran KKPI terutama pada kompetensi dasar mengoperasikan software microsoft excel adalah pengembangan materi pembelajaran dengan menggunakan multimedia pembelajaran sebagai bentuk presentasi (penyajian) dengan memperhatikan aspek pembelajaran dan media sebagai prinsip desain pesan pembelajaran. Penelitian dan pengembangan dilakukan dengan tujuan untuk menghasilkan produk berupa bahan ajar berbasis multimedia sekaligus menguji keefektifan produk yang dapat dimanfaatkan siswa kelas XI SMK Negeri 3 Medan sebagai salah satu strategi untuk meningkatkan kualitas proses pembelajaran dan hasil pembelajaran maupun kompetensi siswa. Oleh karena itu proses penelitan dan pengembagan ini dilakukan dan diawali dengan dengan beberapa tahapan antara lain: (1) melakukan studi pendahuluan, meliputi observasi, wawancara dan studi pustaka. Dari observasi diperoleh gambaran bahwa pembelajaran yang dilakukan oleh guru dikelas cenderung menggunakan pendekatan tradisional, meskipun sebenarnya tersedia fasilitas belajar yang cukup memadai seperti computer dan infocus. (2) mendesain produk untuk menghasilkan produk awal bahan ajar, kegiatan ini meliputi (a) Melakukan penelitian pendahuluan yang meliputi : Indentifikasi kebutuhan dan tujuan pembelajaran, menentukan standar kompetensi mata pelajaran, 
(b) Melakukan analisis pembelajaran dengan menentukan ketrampilan yang lebih khusus yang harus dipelajari, (c) mengindetifikasi karakteristik dan perilaku awal peserta didik, dan (d) menuliskan kompetensi dasar dan indikator; (e) Menyusun tes acuan patokan dengan mengembangkan butir penilaian untuk mengukur kemampuan siswa yang diperkirakan di dalam tujuan pembelajaran; (f) mengembangkan strategi pembelajaran; (3) Mengembangkan bahan ajar, kegiatan ini meliputi pembuatan storyboard dilanjutkan dengan pengumpulan bahan-bahan pendukung seperti foto, video, audio, animasi, dan image yang diperlukan untuk melengkapai bentuk multimedia, (4) Implementasi yaitu kegiatan pemrograman bahan ajar kedalam bentuk multimedia dengan menggunakan software iSpring suite. Dan tahap akhir adalah burning/proses pencetakan media dalam bentuk CD pembelajaran. (5) melakukan evaluasi formatif dan revisi;kegiatan ini meliputi evaluasi produk untuk mengetahui kelebihan, kekurangan dan kelemahan mengenai kualitas isi dan desain yang dilakukan oleh ahli materi, ahli desain dan ahli media, dari hasil evaluasi akan dijadikan bahan untuk dilakukan revisi produk.

Hal ini sejalan dengan pendapat Belawati (2003:105) bahwa evaluasi formatif diartikan sebagai program evaluasi yang dilakukan selama berlangsungnya proses pengembangan dan produksi bahan ajar. Sementara itu menurut Cyntia B.Weston dalam Belawati (2003:105) mengemukakan definisi evaluasi formatif sebagai proses yang digunakan dalam bidang politik, bisnis, industry dan pendidikan untuk mengumpulkan data tentang suatu produk selama proses pengembangan, sehinggga produk tersebut dapat disempurnakan sebelum final. Menurut Belawati (2003:105) dalam pengembangan dan produksi bahan ajar evaluasi, formatif sering dilakukan dalam bentuk kegiatan uji coba terhadap prototype program yaitu bentuk pertama dari sebuah bahan ajar sebelum diaplikasikan pada sasaran. Sementara itu Heinich dkk dalam Belawati (2003:105) menyatakan bahwa tujuan dari pengujian prototype adalah untuk mengetahui kelemahankelemahan yang terdapat pada prototype bahan ajar. Berdasarkan kelemahan-kelemahan tersebut pengembang bahan ajar dapat melakukan perbaikan dan penyempurnaan yang diperlukan sebelum bahan ajar tersebut diproduksi dalam bentuk program final.

Hasil revisi selanjutnya diuji cobakan kepada siswa melalui uji perorangan, uji kelompok kecil dan uji lapangan. Uji coba ini diharapkan mendapatkan umpan balik untuk menghasilkan multimedia pembelajaran yang layak digunakan sesuai dengan karakteristik bidang studi dan sesuai kebutuhan siswa sebagai pengguna. Hal ini sejalan dengan pendapat Borg \& Gall (1983:772) pada buku Education Research; An Introduction yang mengemukakan bahwa penelitian pengembangan adalah penelitian yang berorientasi untuk mengembangkan dan memvalidasi produk-produk yang digunakan dalam pendidikan.

Menurut Belawati (2003:110) sebuah bahan ajar akan dianggap final setelah memperlihatkan hasil yang memuaskan dalam mencapai tujuan yang telah ditentukan. Untuk hal ini diperlukan kegiatan melakukan tes hasil belajar setelah pelaksanaan uji coba produk pada proses pembelajaran untuk mengetahui efektifitas pembelajaran. Untuk melihat efektifitas produk dilakukan analisis terhadap hasil belajar pada 36 siswa yang diajarkan menggunakan bahan ajar berbasis multimedia dan membandingkan dengan hasil belajar pada kelas yang diajarkan dengan buku teks plus presentasi power point. Berdasarkan analisis, nilai rata-rata pada Kompetensi Dasar Mengoperasikan Software Microsoft Excel yang diajar dengan menggunakan bahan ajar bebasis multimedia interaktif adalah 85,08 . Sedangkan hasil belajar siswa yang diajar dengan menggunakan buku teks adalah 77,20. Demikian juga dengan penilaian kemampuan psikomotor, siswa yang diajarkan menggunakan bahan ajar berbasis multimedia memperoleh nilai rata-rata 91,56 dan siswa yang diajarkan menggunakan media buku teks plus presentasi power point memperoleh nilai rata-rata 81,59.

Hasil tersebut diatas menunjukkan adanya perbedaan hasil belajar yang diperoleh, sehingga dapat dinyatakan bahwa terdapat perbedaan hasil belajar baik aspek kognitif dan aspek psikomotor antara kelas yang menggunakan buku teks dengan kelas yang menggunakan bahan ajar berbasis multimedia interaktif. Perolehan hasil belajar menggunakan bahan ajar berbasis multimedia lebih tinggi dibandingkan dengan hasil belajar menggunakan buku teks. 
Terdapat beberapa faktor yang menyebabkan terjadinya perbedaan skor ratarata hasil belajar antara kelas yang menggunakan buku teks dan kelas yang menggunakan bahan ajar berbasis multimedia interaktif. Pertama, pengembangan bahan ajar dilandasi oleh teori komunikasi, teori belajar, dan teori pembelajaran. Teori komunikasi berdampak besar pada paradigma pembelajaran yaitu pemanfaatan media atau sumber belajar dalam pembelajaran. Pesan atau materi yang abstrak akan lebih jelas dan dapat dipahami dengan baik bila berbantuan gambar, audio, video, animasi, atau simulasi. Hal ini sejalan dengan pendapat Mayer (2009:18) yang menyatakan bahwa multimedia menawarkan teknologi pembelajaran yang berpotensi kuat untuk meningkatkan kualitas pembelajaran manusia, orang akan dapat belajar lebih baik dari kata-kata dan gambar daripada hanya dengan kata-kata saja. Bahan ajar yang dikembangkan juga berdasarkan teori belajar.

Proses belajar terjadi karena sinergi memori jangka pendek dan jangka panjang yang diaktifkan melalui penciptaan faktor eksternal yaitu lingkungan belajar, bahwa belajar lebih dominan terjadi dengan cara melihat dan mendengar. Bahan ajar juga dikembangkan berdasarkan teori pembelajaran. Sajian materi pada bahan ajar berlandaskan pada teori pembelajaran Bruner dan peristiwa pembelajaran menurut Gagne. Teori Bruner digunakan sebagai prinsip penyajian materi yaitu dimulai dari hal mudah secara bertahap ke arah materi yang lebih kompleks. Pada bahan ajar, penyajian ini ditunjukkan pada rumusan indikator yang dimulai dari hal mudah hingga ke hal sulit. Rumusan indikator sekaligus menjadi acuan menyajikan isi bahan ajar.

Kedua, penerapan bahan ajar multimedia dipadukan dengan model pembelajaran ekspositori. Bahan ajar multimedia adalah salah satu perangkat pembelajaran. Keefektifan implementasi bahan ajar harus didukung oleh pemilihan model pembelajaran yang tepat. Model pembelajaran ekspositori dinilai relevan dan sesuai dengan karakteristik mata pelajaran dan ketersedian waktu pembelajaran. Kombinasi teknologi multimedia dan desain pembelajaran yang tepat dapat menciptakan lingkungan belajar yang baik menuju pembelajaran efektif. Temuan dan hasil penelitian yang relevan mengindikasikan bahwa pemanfaatan bahan ajar multimedia tidak bisa terlepas dari metode maupun model pembelajaran sebagai bagian dari sebuah desain pembelajaran.

Dengan melihat pedoman dan kriteria penilaian menurut Sugiyono (2010:257) dapat disimpulkan bahwa dari perolehan hasil belajar tersebut membuktikan bahwa penggunaan bahan ajar berbasis multimedia interaktif lebih efektif untuk meningkatkan kompetensi dan pengetahuan siswa pada mata pelajaran KKPI serta layak digunakan sebagai media pembelajaran pada mata pelajaran KKPI di SMK Negeri 3 Medan.

Hasil peneltian ini sejalan penelitian Prabawa (2013) dalam tesisnya yang berjudul Pengembangan Bahan Ajar Multimedia Berbasis Proyek Pada Mata Pelajaran Produksi Audio Dan Video di SMK Negeri 1 Sukasada menunjukkan hasil bahwa terdapat perbedaan yang signifikan hasil belajar siswa antara sebelum belajar menggunakan bahan ajar multimedia dan setelah belajar menggunakan bahan ajar multimedia. Tingkat keefektifan bahan ajar multimedia berbasis proyek meningkatkan hasil belajar adalah tinggi. Ini berarti bahwa hasil belajar peserta didik meningkat setelah menggunakan bahan ajar berbasis multimedia interaktif.

Demikian juga dengan dengan penelitian yang dilakukan oleh Ali (2009) dalam tesisnya yang berjudul Pengembangan Media Pembelajaran Interaktif Mata Kuliah Medan Elektromagnetik. Hasil penelitiannya menunjukkan bahwa media pembelajaran yang dikembangkan memberikan manfaat dan nilai tambah yang sangat signifikan kepada mahasiswa terutama sebagai bahan untuk belajar mandiri.

\section{PENUTUP \\ Simpulan}

1. Produk bahan ajar berbasis multimedia interaktif yang dikembangkan untuk mata pelajaran KKPI memenuhi syarat dan layak digunakan sebagai media pembelajaran, berdasarkan hasil validasi ahli terhadap multimedia pembelajaran pada mata pelajaran KKPI yang dikembangkan menunjukkan secara keseluruhan dalam kategori "Sangat Baik" sehingga layak digunakan dalam proses pembelajaran.

2. Hasil validasi dari ahli media pembelajaran terhadap multimedia pembelajaran pada mata pelajaran KKPI yang dikembangkan 
menunjukkan secara keseluruhan dalam kategori "Baik" sehingga layak digunakan dalam proses pembelajaran.

3. Hasil uji coba produk pada uji coba perorangan menujukkan bahwa untuk kualitas materi pembelajaran dinilai sangat baik, sedangkan untuk kualitas teknis atau tampilan dinilai sangat baik program iSpring suite sehingga dapat layak digunakan dalam proses pembelajaran.

4. Hasil uji coba produk pada uji coba kelompok kecil terdiri dari Sembilan orang siswa menujukkan bahwa untuk kualitas materi pembelajaran dinilai sangat baik, sedangkan untuk kualitas teknis atau tampilan dinilai sangat baik dengan menggunakan program iSpring suite sehingga layak digunakan dalam proses pembelajaran.

5. Hasil uji coba produk pada uji coba lapangan terdiri dari 36 orang siswa menujukkan bahwa untuk kualitas materi pembelajaran dinilai sangat baik, sedangkan untuk kualitas teknis atau tampilan dinilai sangat baik sehingga layak digunakan dalam proses pembelajaran.

6. Penggunaan bahan ajar berbasis Multimedia interaktif lebih efektif dibandingkan dengan penggunaan buku teks; (1) Penggunaan bahan ajar berbasis multimedia interaktif lebih efektif meningkatkan hasil belajar, hal ini ditunjukkan oleh hasil belajar yang menggunakan multimedia pembelajaran memperoleh nilai rata-rata 89,61, dibanding dengan kelas yang diajar dengan menggunakan buku teks memperoleh nilai rata-rata 80,71 ; (2) Terdapat perbedaan hasil belajar siswa yang diajar dengan multimedia pembelajaran interaktif dibandingkan dengan siswa yang diajar dengan buku teks, dengan $t_{\text {hitung }}$ sebesar 5,39 , sedangkan $t_{\text {tabel }}$ pada taraf $\alpha=0,05$ dengan $\mathrm{dk} 70$ adalah 1,66 , atau thitung $>$ $\mathrm{t}_{\text {tabel }} ;(5,39>1,66)$.

\section{Saran}

1. Selama ini proses pembelajaran yang dilaksanakan pada mata pelajaran adaptif umumnya masih menggunakan bahan pembelajaran cetak, sehingga sering terjadi kebosanan pada peserta didik, hal ini dapat menyebabkan tidak tercapainya kemampuan dalam menangkap dan mengaplikasikan ilmu yang diperoleh, maka perlu diupayakan kearah pembelajaran yang berbasis multimedia.

2. Multimedia pembelajaran KKPI memerlukan fasilitas terutama perangkat komputer yang mencukupi, sehingga dari pembelajaran berkelompok dapat dilanjutkan dengan pembelajaran mandiri. Penngadaan computer harus menjadi pertimbangan pihak sekolah atau orang tua.

3. Multimedia pembelajaran KKPI hanya sebagai alat untuk membantu dalam proses penyampaian pembelajaran khususnya pada mata pelajaran KKPI, oleh karena itu keberadaan guru masih diperlukan sebagai fasilitator dan siswa tetap terlibat aktif dalam proses pembelajaran.

4. Pada kenyataanya hingga saat ini proses pembelajaran pada mata pelajaran KKPI masih dilakukan dengan cara konvensional dengan menggunakan buku teks, maka disarankan agar multimedia pembelajaran KKPI mulai saat ini sudah harus digunakan dengan alasan multimedia pembelajaran KKPI mampu memberi umpan balik yang lebih baik bagi siswa.

\section{DAFTAR PUSTAKA}

Ali, Muhammad. 2009. Pengembangan Media Pembelajaran Interaktif Mata Kuliah Medan Elektromagnetik.

Arief S. Sadiman, R. Raharjo, dan Anung Haryono. (2006). Media pendidikan: pengertian, pengembangan dan pemanfaatannya. Jakarta: Pustekkom Dikbud dan Raja Grafindo Perkasa.

Azhar Arsyad. (2006). Media pembelajaran. Jakarta: Raja Grafindo Persada.

Belawati, Tian. 2003. Pengembangan Bahan Ajar. Jakarta: Pusat Penerbitan Universitas Terbuka

Bigge,Morris L. 1982. Learning Theories for Teachers. Harper \& Row Publishers, Inc. New York.

Borg, W. R., \& Gall, M. D. (2003). Educational research: an introduction (7th Ed.). New York: Logman, Inc.

Budiningsih, Asri C. 2005. Belajar dan Pembelajaran. Jakarta : Rineka Cipta.

Dahar,Wilis D.2006. Teori-Teori Belajar \& Pembelajaran. Jakarta: Erlangga.

Daryanto, 2012. Media Pembelajaran. Bandung: Sarana Tutorial Nurani Sejahtera.

Depdiknas. 2007. Materi Sosialisasi dan pelatihan Kurikulum Tingkat Satuan 
Pendidikan (KTSP) SMK. Jakarta: Depdiknas RI.

Dick, W., Carey, L., Carey, J.O. (2005). The systematic design of instruction (6th Ed.). Boston: Scott, Pearson A.B.

Dimyati, Mudjiono. 2009. Belajar Dan Pembelajaran. Jakarta : Rineka Cipta.

Djamarah. 2005. Strategi Belajar Mengajar. Jakarta: Rineka Cipta

Hamalik, Oemar. 2004. Proses Belajar Mengajar. Jakarta : Bumi Aksara.

Hamid, Abdul K.2009, Teori Belajar dan Pembelajaran (edisi kedua), Medan. ISBN : 878-979-25-1825-2.

Heinich, Molenda, Russel, Smaldino. (1996). Instructional Media and Technologies for Learning. New Jersey: Printice-Hall, Inc. A Simon \& Schuster Company.

Hergenhahn, Olson. 2008. Theories Of Learning. ( Dialihbahasakan oleh Tri Wibowo B.S). Jakarta: Kencana Prenada Media Group.

Kustandi, Cecep., dkk. 2011. Media Pembelajaran. Bogor: Ghalia Indonesia.

Kemdiknas. 2010. Juknis Pengembangan Bahan Ajar SMA. Jakarta: Kemdiknas RI.

Krathwohl, David., Anderson, Orin. 2001. A Taxonomy For Learning, Teaching, And Assessing. New York: Addison Wesley Longman,Inc.

Meyer, Ricchar E. 2009. Multimedia LearningPrinsip dan Aplikasi.Yogyakarta:Pustaka Pelajar.

Miarso, Yusufhadi. 2004. Menyemai Benih Teknologi Pendidikan. Prenada Media, Jakarta.

Molenda,Michael., Januszewski,Alan. 2008. Educational Technology. New York : Lawrence Erlbaum Associates.

Munadi, Yudhi. 2013. Media Pembelajaran. Jakarta : Referensi ( GP Press Group).

Nana Sudjana \& Ahmad Rivai. (2005). Media pengajaran. Jakarta: Sinar Baru Algensindo.

Prabawa, P, Santyasa. Warpala. 2013). Pengembangan bahan ajar multimedia berbasis proyek Pada mata pelajaran produksi audio dan video di SMK Negeri 1 sukasada. e-Journal Program Pascasarjana Universitas Pendidikan Ganesha Program Studi Teknologi Pembelajaran .Volume 3.

Prastowo, Andi. 2011. Panduan kreatif Membuat Bahan Ajar Inovatif. Yogyakarta;Diva Press
Purnomo, Andi. 2004. Presentasi Multimedia Dengan Macromedia Flash. Yogyakarta : Andi Offset

Riyanto,Yatim,H. 2012. Paradigma Baru pembelajaran. Jakarta: Kencana Prenada Media Group.

Rosett, Allison \& Arwady W Joseph. 1989. Training Needs Assessment. New Jersey : Educational Technology Publication New Jersey.

Rusman. 2012. Belajar dan Pembelajaran Berbasis Komputer. Bandung; Alfabeta

Sanjaya, Wina. 2010. Perencanaan dan Desain Sistem Pembelajaran. Jakarta: Prenada Media Group.

Siddik,dkk. 2008. Pengembangan Bahan Ajar. Direktorat Jenderal Pendidikan Tinggi, DEPDIKNAS.

Subarna,S. 2012.Penggunaan software camtasia studio 8 sebagai media Pembelajaran KKPI klas XI SMK N 1 klaten tahun 2012. Jurnal Seruni FTI UNSA. 2012 Volume 1- ISSN: 2302-1136.

Suparman, Atwi M. 2001. Desain Instruksional. Jakarta : Pusat Antar Universitas Untuk Peningkatan Dan Pengembangan Aktivitas Instruksional Direktorat Jenderal Pendidikan Tinggi Depertemen Pendidikan Nasional.

Suryosubroto, 2002. Proses Belajar Mengajar di Sekolah, Rieneka Cipta, Jakarta.

Sutopo, Ariesto H. 2003. Multimedia Interaktif dengan Flash. Yogyakarta: Graha Ilmu.

Sutrisno, 2011. Pengantar Pembelajaran Inovatif. Jakarta : Gaung Persada( GP ) Press

Swajati. 2005. Belajar Sendiri: Membuat CDMultimedia Interaktif untuk Bahan Ajar E-Learning. Jakarta: PT Elek Media Komputindo.

Trianto. 2009. Mendesain Model pembelajaran Inovatif-Progresif. Jakarta: Kencana Prenada Media Group.

Uno, Hamzah B. 2010. Perencanaan Pembelajaran. Jakarta : Sinar Grafika Affset

Wena, Made. 2011. Strategi Pembelajaran Inovatif Kontemporer. Jakarta: Bumi Aksara

Wina Sanjaya. (2006). Strategi pembelajaran berorientasi standar proses pendidikan. Jakarta: Kencana Prenada Media. 